\title{
Potato Virus A Isolates from Three Continents: Their Biological Properties, Phylogenetics, and Prehistory
}

\author{
Segundo Fuentes, ${ }^{1}$ Adrian J. Gibbs, ${ }^{2}$ Ian P. Adams,${ }^{3}$ Calum Wilson, ${ }^{4}$ Marleen Botermans, ${ }^{5}$ Adrian Fox,${ }^{3}$ Jan Kreuze, ${ }^{1}$ Neil \\ Boonham, ${ }^{6}$ Monica A. Kehoe, ${ }^{7}$ and Roger A. C. Jones ${ }^{8, \dagger}$ \\ ${ }^{1}$ Crop and System Sciences Division, International Potato Center (CIP), La Molina, Lima, Peru \\ ${ }^{2}$ Emeritus Faculty, Australian National University, Canberra, ACT, Australia \\ ${ }^{3}$ Fera Science Ltd., Sand Hutton, York, U.K. \\ ${ }^{4}$ Tasmanian Institute of Agriculture, New Town Research Laboratories, University of Tasmania, New Town, Tasmania, Australia \\ ${ }^{5}$ National Reference Centre of Plant Health, Dutch National Plant Protection Organization Service, Wageningen, The Netherlands \\ ${ }^{6}$ Institute for Agrifood Research Innovations, Newcastle University, Newcastle upon Tyne, U.K. \\ ${ }^{7}$ Diagnostic Laboratory Services, Department of Primary Industries and Regional Development, South Perth, WA, Australia \\ ${ }^{8}$ Institute of Agriculture, University of Western Australia, Crawley, WA, Australia \\ Accepted for publication 5 November 2020.
}

\begin{abstract}
Forty-seven potato virus A (PVA) isolates from Europe, Australia, and South America's Andean region were subjected to high-throughput sequencing, and 46 complete genomes from Europe $(n=9)$, Australia $(n=2)$, and the Andes $(n=35)$ obtained. These and 17 other genomes gave alignments of 63 open reading frames 9,180 nucleotides long; 9 were recombinants. The nonrecombinants formed three tightly clustered, almost equidistant phylogroups; A comprised 14 Peruvian potato isolates; W comprised 37 from potato in Peru, Argentina, and elsewhere in the world; and T contained three from tamarillo in New Zealand. When five isolates were inoculated to a potato cultivar differential, three strain groups (= pathotypes) unrelated to phylogenetic groupings were recognized. No temporal signal was detected among the dated nonrecombinant sequences, but PVA and potato virus Y (PVY) are from related lineages and ecologically similar; therefore, "relative dating" was obtained using a single maximum-likelihood phylogeny of PVA and PVY sequences and PVY's well-supported 157 CE 'time to

most common recent ancestor". The PVA datings obtained were supported by several independent historical coincidences. The PVA and PVY populations apparently arose in the Andes approximately 18 centuries ago, and were taken to Europe during the Columbian Exchange, radiating there after the mid-19th century potato late blight pandemic. PVA's phylogroup A population diverged more recently in the Andean region, probably after new cultivars were bred locally using newly introduced Solanum tuberosum subsp. tuberosum as a parent. Such cultivars became widely grown, and apparently generated the A $\times$ W phylogroup recombinants. Phylogroup A, and its interphylogroup recombinants, might pose a biosecurity risk.

Keywords: American lineage, biosecurity significance, dating, disease resistance, evolution, genomics, high-throughput sequencing, interpretation, pathotyping, phylogenetic analysis, population biology, Potato virus $A$, prehistory, strain groups, virology
\end{abstract}

Potato virus A (PVA) (species Potato virus A, genus Potyvirus, family Potyviridae) is transmitted nonpersistently by aphids and has flexuous

${ }^{\dagger}$ Corresponding author: R. A. C. Jones; roger.jones@uwa.edu.au

Funding: In 2015 to 2019, the main sequencing component of this research was funded at the CIP by the CGIAR Research Program on Roots, Tubers and Bananas (RTB), CGIAR trust fund contributors (https://www.cgiar.org/funders/), the Peruvian Programa Nacional de Innovación Agraria (contract 029-2015-INIAPNIA/UPMSI/IE), and the Bill and Melinda Gates Fund; and at Fera Science Ltd. (FS) by the United Kingdom Government's Department of Environment Food and Rural Affairs (DEFRA) Future Proofing Plant Health Project under the Defra-Fera Science Ltd. long-term services agreement, and via the EUPHRESCO VirusCurate project. Funding for sequencing was also provided by The Netherlands Plant Protection Service (NPPS), Wageningen, The Netherlands; the Department of Primary Industries and Regional Development (DPIRD), South Perth, Australia; and the University of Western Australia (UWA). The biological component of this research was done at the Ministry of Agriculture, Fisheries and Food (MAFF), Harpenden, U.K. in 1985 to 1986, and the Tasmanian Institute of Agriculture (TIA), New Town Research Laboratories, Australia in 2014 to 2015.

A. J. Gibbs is an Emeritus Professor at the Australian National University, Canberra, and R. A. C. Jones is currently an Adjunct Professor at UWA but was an employee of MAFF in 1979 to 1986, where experiments 1 and 2 were done.

*The $\boldsymbol{e}$-Xtra logo stands for "electronic extra" and indicates that a supplementary table is published online.

The author(s) declare no conflict of interest.

Copyright (C) 2021 The Author(s). This is an open access article distributed under the CC BY 4.0 International license. filamentous virions $730 \mathrm{~nm}$ long and $15 \mathrm{~mm}$ in diameter (Bartels 1971; Fribourg and de Zoeten 1970). Its virions consist of many copies of a virus coded coat protein $(\mathrm{CP})$ which encapsulates a singlestranded, positive-sense RNA 9,565 nucleotides (nt) in length. It infects potato (Solanum tuberosum) crops worldwide and the potato tuber yield losses that result from single infections can reach $40 \%$, although they are normally considerably smaller than this. However, mixed infection with PVA and potato virus X, which causes potato "crinkle disease", results in more substantial losses (Bartels 1971; de Bokx and van der Want 1987; German 2001; He et al. 2014; Jones 2014; Kreuze et al. 2020; Loebenstein et al. 2001; Murphy and McKay 1932a; Valkonen 2007). In general, infection with PVA in the field is restricted to a small number of potato cultivars that lack PVA hypersensitivity genes $N a$ and $N a_{K E}$ (Cockerham 1943, 1970; Jones 1987; Valkonen et al. 1995). For this reason and the mild foliage symptoms (mild mosaic, rugosity, and waviness of leaf margins) or symptomless infection it causes in cultivars lacking these two genes (Bartels 1971; de Bokx and van der Want 1987), some countries don't include it in routine tests for common potato viruses when certifying healthy seed potato (He et al. 2014; Jones 2014; Kreuze et al. 2020; Valkonen 2007).

PVA was among the earliest potato viruses found (Bald and Pugsley 1941; Bartels 1971; Bawden and Sheffield 1944; Clinch et al. 1936; Cockerham 1943; MacLachlan et al.1954; Murphy and McKay 1932b; Smith 1957). It was apparently present in early potato shipments to Europe as part of the "Columbian Exchange", which commenced in approximately 1570 CE (Hawkes 1990; Nunn 
and Qian 2010). Like several other potato viruses, it then spread worldwide with the expanding potato crop. Early studies found that PVA isolates differ in virulence when they infect potato plants. Therefore, relative foliage symptom severity was used to differentiate them into four biological strain groups: very mild, mild, moderately severe, and severe (Bartels 1971). Subsequently, Valkonen et al. (1995) distinguished three different strain groups (= pathotypes) based on whether a PVA isolate caused systemic necrosis (PVA-1), mottle (PVA-2), or no infection (PVA-3) following graft inoculation to potato cultivar King Edward. Soon afterward, Rajamäki et al. (1998) added an additional strain group that differed in causing systemic yellowing and stunting in King Edward (PVA-4). Isolates belonging to PVA-1 elicit potato hypersensitivity gene $\mathrm{Na}$, which is present in Maris Piper potato and many other cultivars (Cockerham 1943, 1970; Howard and Fuller 1965; Jones 1987, 1990) and hypersensitivity gene $\mathrm{Na}_{K E}$ carried by King Edward (SolomonBlackburn and Barker 2001; Valkonen et al. 1995). By contrast, PVA2 isolates overcome $N a_{K E}$ in King Edward. PVA-3 isolates cause mild or asymptomatic susceptible phenotypes in a few cultivars but fail to infect most, including King Edward and Maris Piper (Rajamäki et al. 1998; Valkonen et al. 1995). PVA-4 isolates differ from PVA-2 isolates in causing a more severe susceptible phenotype in King Edward (Rajamäki et al. 1998).

When Rajamäki et al. (1998) analyzed the phylogeny of the CP sequences of 18 PVA isolates from different countries, considerable sequence diversity was found; however, this diversity was only partially explained by geographical factors related to country of origin. Kekarainen et al. (1999) made similar analyses with four complete genomes of the virus from European potato and isolate TamMV from tamarillo ( $S$. betaceum) in New Zealand (Eagles et al. 1990, 1994; Mossop 1977). TamMV proved to be the most divergent isolate. When Mortensen et al. (2010) compared the CP sequences of nine PVA isolates from Scotland's Shetland Islands with CP sequences available from elsewhere (Europe, East Asia, and North America), they found that most belonged to one of two minor phylogroups. Subsequently, He et al. (2014) compared the genome of a Chinese isolate with seven other genomes from Europe, North America, and New Zealand. TamMV was again the most distinct isolate. Most recently, Nisbet et al. (2019) described a new potyvirus from potato in Scotland. Its genome had a $72 \%$ nucleotide sequence identity with PVA, and was named potato yellow blotch virus (PYBV). When Gibbs et al. (2020) examined the phylogenetics of potyviruses, PVA, PYBV, and tobacco vein mottling virus grouped together, whereas the three other potato potyviruses- potato virus $\mathrm{Y}$ (PVY), potato virus $\mathrm{V}$ (PVV), and wild potato mosaic virus - were in the close but distinct PVY lineage, all three of them being from the Americas.

The interpretation of phylogenies is greatly enhanced if they are dated. Various statistical techniques (Rutschmann 2006) have been devised for dating phylogenies of organisms that, like potyviruses, are evolving at measurable rates; the phylogenies are dated by the temporal signal obtained from gene sequences collected on different dates (i.e., heterochronous samples). However, all depend of the serendipitous availability of sequences sampled over decades - the longer the time range the better - and it is also important that the full phylogenetic diversity of the population is sampled. As we report below, the PVA data in this article appears to have no temporal signal. Fortunately, however, the world population of a closely related virus, PVY, has been dated convincingly (Fuentes et al. 2019; Gao et al. in press; Gibbs et al. 2017). PVY has the same principal solanaceous host (potato) and transmission modes (i.e., tuber and aphids). Therefore, we made a maximum-likelihood (ML) phylogeny (Guindon and Gascuel 2003) of representative PVA and PVY sequences and used the relative node positions of its PVA and PVY "subtrees" to provide relative dating of PVA by extrapolating from the published dates for PVY (Hajizadeh et al. 2019; Mohammadi et al. 2018). This is possible because, in a single ML phylogeny, the relationships of all sequences are described by a single statistical model; thus, phylogenetic differences in different parts of the tree can be compared and, with closely related viruses, similarities or differences in their phylogenetic distances are more likely to be related to their dates of origin than their rates of evolution. It is worth noting that the node dates in a maximum clade credibility (MCC) tree from a BEAST analysis (Drummond et al. 2012) and the dates of an ML tree dated using patristic distances from the time to most recent common ancestor (TMRCA) of the MCC tree are linearly related (Fuentes et al. 2019).

This article provides new information about the biological properties of four PVA isolates from Europe or Australia and establishes which biological strain groups they belong to. It also presents the complete genomic sequences of 46 new PVA isolates from Europe, Australia, and the Andean region of South America, provides new information about the phylogenetics of PVA by comparing these new sequences with 17 complete genome and 26 CP PVA sequences from GenBank, and enhances our understanding of the prehistory of this virus.

\section{MATERIALS AND METHODS}

Virus isolates and plants. For each PVA isolate, where available, the potato cultivars they originally came from, years of first isolation, geographical origins, biological strain groupings, and first isolate typing references are provided in Table 1 . They included historical European isolates from France (622), Scotland (GW), and Switzerland $(608,613$, and 775) held in a collection of historic freeze-died virus isolates kept at FERA Science Ltd., York, U.K., and two more recent Australian isolates obtained by the Tasmanian Institute of Agriculture, University of Tasmania, Hobart, TAS, Australia (PE) and the Western Australian Department of Primary Industries and Regional Development, Perth, WA, Australia (KIP). Isolates 608, 613, 622, and 775 were kindly supplied in 1985 as dried infected leaf material previously desiccated over calcium chloride by Dr. Paul Gugerli of the Swiss Agricultural Research Station, Nyon, Switzerland. Isolate 22 was a subculture from isolate 622. Isolate GW was from Dr. Tom Davidson, Scottish Plant Breeding Station, Pentlandfield, Scotland, and Jones (1990) described biological studies done with it in 1982 to 1985 . The biological studies with isolates $608,613,622$, and 775 described below were done at the Ministry of Agriculture, Fisheries and Food (MAFF), Harpenden Laboratory, England in 1985 to 1986 . Leaves infected with these five historical isolates were freeze dried in $1984(\mathrm{GW})$ or in 1986 (the other four isolates). Isolate PE was kindly provided in infected cultivar Pink Eye potato tubers by Dr. Gradon Johnstone, Department of Primary Industries, Water and Environment, New Town Research Laboratories, Tasmania. Isolate KIP came from an infected tuber of potato cultivar Kipfler. The biological studies with isolate PE described below were done in 2014 to 2015 in Australia; none were done with isolate KIP. English isolates 20922289 and 20910846 were from cultivars Hermes and Marfona, and Norwegian isolates 21619718 and 21619719 were from unknown potato cultivars kindly supplied by Ola Johansen, Norwegian Food Safety Authority, Mattilsynet, Norway. Three isolates originated from a consignment of "native potato" tubers originating from the Andean region that had been intercepted at Amsterdam Schiphol airport in The Netherlands.

Isolates from Peru consisted of three groups: 27 were obtained from leaves derived from 994 individual potato plants collected between 2016 to 2018 in the northern, central, and southern Andean highlands of Peru (Fig. 1); and 5 came from native potato land race accessions in the International Potato Center (CIP) in vitro germplasm collection, 2 of which originated from Argentina and 3 from Peru (Table 1). The 994 potato plants sampled showed foliage symptoms indicative of virus infection and came from nine Peruvian departments (north: Cajamarca; center: Huanuco, Junin, Huancavelica, Lima, and Ica; and south: Apurimac, Cusco, and Puno). Each sample was placed in a separate labeled paper filter 
TABLE 1 . Origins and accession numbers of the 47 potato virus A isolates from three continents used

\begin{tabular}{|c|c|c|c|c|c|c|}
\hline Isolate & $\begin{array}{l}\text { Source potato } \\
\text { cultivar }\end{array}$ & Species $^{\mathrm{a}}$ & Where collected & Isolation year & Accession number & $\begin{array}{l}\text { Isolate } \\
\text { reference }\end{array}$ \\
\hline GW & Golden Wonder & $\begin{array}{l}\text { Solanum tuberosum subsp. } \\
\text { tuberosum }\end{array}$ & Scotland & $\begin{array}{l}\text { Received } 1982 \text { ex Tom } \\
\text { Davidson }\end{array}$ & MT435488 & $\begin{array}{l}\text { Jones } \\
(1990)\end{array}$ \\
\hline PE & Pink Eye & S. tuberosum subsp. tuberosum & Tasmania, Australia & $\begin{array}{l}\text { Received } 1992 \text { ex Gradon } \\
\text { Johnstone }\end{array}$ & MT435495 & This article \\
\hline KIP & Kipfler & S. tuberosum subsp. tuberosum & $\begin{array}{l}\text { Queensland, } \\
\text { Australia }\end{array}$ & $\begin{array}{l}\text { Ex supermarket purchased } \\
\text { tuber } 2008\end{array}$ & MT435489 & This article \\
\hline $\begin{array}{l}608 \text { (sub culture } \\
\text { ex } 613 \text { ) }\end{array}$ & Advira & S. tuberosum subsp. tuberosum & Switzerland & $\begin{array}{l}\text { Received } 1985 \text { ex Paul Gugerli } \\
\text { (P. G.) }\end{array}$ & $\begin{array}{l}\text { Biological data, no } \\
\text { sequence }\end{array}$ & This article \\
\hline 613 & Advira & S. tuberosum subsp. tuberosum & Switzerland & Received 1985, ex P.G. & MT435492 & This article \\
\hline 22 (sub culture & & & & & & \\
\hline ex 622) & Viola & S. tuberosum subsp. tuberosum & France & Received 1985, ex P.G. & MT435485 & This article \\
\hline 622 & Viola & S. tuberosum subsp. tuberosum & France & Received 1985, ex P.G. & MT435493 & This article \\
\hline 775 & Sirtema & S. tuberosum subsp. tuberosum & Switzerland & Received 1985, ex P.G. & MT435494 & This article \\
\hline HER & Hermes & S. tuberosum subsp. tuberosum & England & Ex Fera, 2009 & MT435487 & This article \\
\hline MAR & Marfona & S. tuberosum subsp. tuberosum & England & Ex Fera, 2009 & MT435486 & This article \\
\hline $9 \mathrm{C}$ & Unknown & S. tuberosum subsp. tuberosum & Norway & $\begin{array}{l}\text { Received, } 2009 \text { ex Ola } \\
\text { Johansen }\end{array}$ & MT435491 & This article \\
\hline 14D & Unknown & S. tuberosum subsp. tuberosum & Norway & $\begin{array}{l}\text { Received, } 2009 \text { ex Ola } \\
\text { Johansen }\end{array}$ & MT435490 & This article \\
\hline Apu003 & Huayro & Solanum $\times$ chaucha & Apurimac, Peru & Collected, 2018 & MT502351 & This article \\
\hline Apu007 & Putis & Solanum $\times$ chaucha & Apurimac, Peru & Collected, 2018 & MT502352 & This article \\
\hline Apu046 & Huayro & Solanum $\times$ chaucha & Apurimac, Peru & Collected, 2018 & MT502353 & This article \\
\hline Apu047 & Peruanita & $\begin{array}{l}\text { S. stenotomum subsp. } \\
\text { goniocalyx }\end{array}$ & Apurimac, Peru & Collected, 2018 & MT502354 & This article \\
\hline Apu048 & Huayro & Solanum $\times$ chaucha & Apurimac, Peru & Collected, 2018 & MT502355 & This article \\
\hline Apu061 & Huayro & Solanum $\times$ chaucha & Apurimac, Peru & Collected, 2018 & MT502356 & This article \\
\hline Apu063 & Ccompis & S. tuberosum subsp. andigena & Apurimac, Peru & Collected, 2018 & MT502357 & This article \\
\hline Apu064 & Huayro & Solanum $\times$ chaucha & Apurimac, Peru & Collected, 2018 & MT502358 & This article \\
\hline Apu066 & Huayro & Solanum $\times$ chaucha & Apurimac, Peru & Collected, 2018 & MT502359 & This article \\
\hline Apu070 & Huayro & Solanum $\times$ chaucha & Apurimac, Peru & Collected, 2018 & MT502360 & This article \\
\hline Apu070A & Huayro & Solanum $\times$ chaucha & Apurimac, Peru & Collected, 2018 & MT502361 & This article \\
\hline Apu074 & Peruanita & $\begin{array}{l}\text { S. stenotomum subsp. } \\
\text { goniocalyx }\end{array}$ & Apurimac, Peru & Collected, 2018 & MT502362 & This article \\
\hline Apu076 & Peruanita & $\begin{array}{l}\text { S. stenotomum subsp. } \\
\text { goniocalyx }\end{array}$ & Apurimac, Peru & Collected, 2018 & MT502363 & This article \\
\hline Apu077 & Peruanita & $\begin{array}{l}\text { S. stenotomum subsp. } \\
\text { goniocalyx }\end{array}$ & Apurimac, Peru & Collected, 2018 & MT502364 & This article \\
\hline Apu078 & Peruanita & $\begin{array}{l}\text { S. stenotomum subsp. } \\
\text { goniocalyx }\end{array}$ & Apurimac, Peru & Collected, 2018 & MT502365 & This article \\
\hline Apu081 & Huayro & Solanum $\times$ chaucha & Apurimac, Peru & Collected, 2018 & MT502366 & This article \\
\hline Apu082 & Huayro & Solanum $\times$ chaucha & Apurimac, Peru & Collected, 2018 & MT502367 & This article \\
\hline Apu084 & Huayro & Solanum $\times$ chaucha & Apurimac, Peru & Collected, 2018 & MT502368 & This article \\
\hline Apu087 & Huayro & Solanum $\times$ chaucha & Apurimac, Peru & Collected, 2018 & MT502369 & This article \\
\hline Apu090 & Huayro & Solanum $\times$ chaucha & Apurimac, Peru & Collected, 2018 & MT502370 & This article \\
\hline Apu090A & Huayro & Solanum $\times$ chaucha & Apurimac, Peru & Collected, 2018 & MT502371 & This article \\
\hline Cus079 & Huayro & Solanum $\times$ chaucha & Cusco, Peru & Collected, 2016 & MT502372 & This article \\
\hline Cus080 & Huayro & Solanum $\times$ chaucha & Cusco, Peru & Collected, 2016 & MT502373 & This article \\
\hline Hco003B & Tumbay & $\begin{array}{l}\text { S. stenotomum subsp. } \\
\text { goniocalyx }\end{array}$ & Huanuco, Peru & Collected, 2016 & MT502374 & This article \\
\hline Hco004B & Tumbay & $\begin{array}{l}\text { S. stenotomum subsp. } \\
\text { goniocalyx }\end{array}$ & Huanuco, Peru & Collected, 2016 & MT502375 & This article \\
\hline Hco037 & Yungay & $\begin{array}{l}\text { S. tuberosum subsp. andigena } \\
\times \text { tuberosum }\end{array}$ & Huanuco, Peru & Collected, 2016 & MT502376 & This article \\
\hline Pun010 & Huaycha & S. tuberosum subsp. andigena & Puno, Peru & Collected, 2018 & MT502377 & This article \\
\hline CIP703867 & Muru Carhuina & $\begin{array}{l}\text { S. stenotomum subsp. } \\
\text { goniocalyx } \times \text { S. stenotomum } \\
\text { subsp. stenotomum }\end{array}$ & $\begin{array}{l}\text { Cerro de Pasco, } \\
\text { Pasco, Peru }\end{array}$ & $\begin{array}{l}\text { Acquired 1974, International } \\
\text { Potato Center (CIP) }\end{array}$ & MT502378 & This article \\
\hline CIP704104 & Tarmeña Roja & Solanum $\times$ chaucha & Junin, Peru & Acquired 1976, CIP & MT502379 & This article \\
\hline CIP706138 & Puka Palta & S. tuberosum subsp. andigena & Cusco, Peru & Acquired 1986, CIP & MT502380 & This article \\
\hline CIP705869 & $\begin{array}{l}\text { Collareja } \\
\text { Churqueña }\end{array}$ & S. tuberosum subsp. andigena & Jujuy, Argentina & Acquired 1987, CIP & MT502381 & This article \\
\hline CIP710179 & Runa & S. tuberosum subsp. andigena & Jujuy, Argentina & Acquired 1987, CIP & MT502382 & This article \\
\hline 4631723 & $\begin{array}{l}\text { Andean native } \\
\text { cultivar } 1\end{array}$ & Unknown & $\begin{array}{l}\text { Amsterdam } \\
\text { Schiphol airport }\end{array}$ & 2016 & MT521081 & This article \\
\hline 5998981 & $\begin{array}{l}\text { Andean native } \\
\text { cultivar } 2\end{array}$ & Unknown & $\begin{array}{l}\text { Amsterdam } \\
\text { Schiphol airport }\end{array}$ & 2016 & MT521082 & This article \\
\hline 4631741 & $\begin{array}{l}\text { Andean native } \\
\text { cultivar } 3\end{array}$ & Unknown & $\begin{array}{l}\text { Amsterdam } \\
\text { Schiphol airport }\end{array}$ & 2016 & MT521083 & This article \\
\hline
\end{tabular}

${ }^{a}$ The species nomenclature system being used in this table is that of International Potato Center (CIP) (Hawkes 1990). S. stenotomum is diploid, Solanum $\times$ chaucha is triploid, and $S$. tuberosum is tetraploid. 
bag, nine of which were placed together in a zip-lock plastic bag with $100 \mathrm{~g}$ of dehydrated silica gel for rapid desiccation. The silica gel was changed after 24 to $48 \mathrm{~h}$ and the combined samples were taken to CIP in Lima for processing. Samples from in vitro germplasm were processed directly from $100 \mathrm{mg}$ of harvested in vitro culture leaves.

Inoculations and virus cultures. Graft inoculations with PVA-infected scions were standard top grafts done as described by Jones (1990). Sap inoculations in England were done by grinding PVA-infected leaves in an extraction buffer of $0.05 \mathrm{M}$ phosphate ( $\mathrm{pH} 7.0$ ) containing $0.1 \%$ sodium sulfite and rubbing this onto leaves of healthy plants dusted with 600-mesh carborundum powder abrasive. In Australia, PVA-infected leaves were ground in $0.2 \mathrm{M}$ phosphate buffer ( $\mathrm{pH} 7.4$ ) containing $1 \%$ cysteine mixed with diatomaceous earth (Celite) abrasive and rubbing this extract onto leaves of healthy plants. In England, after their initial recovery by inoculation of extracts from desiccated leaves to plants of Nicotiana debneyi and White Burley tobacco, isolates 608, 613, 622 , and 775 were maintained by serial subculture in these same two hosts. In Australia, a culture of isolate PE was maintained by serially replanting infected Pink Eye daughter tubers.

Biological studies. Plants of White Burley tobacco, N. debneyi, and potato were grown in standard potting mix in insect-proofed glasshouses maintained at 18 to $22^{\circ} \mathrm{C}$. For experiments 1 and 2, healthy tubers of cultivar King Edward were sourced from previous studies (Jones 1990). For experiments 3 to 5, healthy tubers of potato cultivars were obtained from the Tasmanian National Potato Culture Collection or, in the case of Yukon Gold, from the Western Australian Department of Primary Industries and Regional Development. Details of cultivar names, parentage (where known), and indicative resistance to PVA are provided in Table 1.

In experiment 1 , one scion from an $N$. debneyi or tobacco plant infected with PVA isolates 608, 613, 622, and 775 was inoculated to each of two to three plants of potato King Edward per isolate (1 scion/ plant); experiment 2 was similar but differed from experiment 1 in lacking graft inoculations with isolate 775 and including four inoculated plants per isolate and 2 to 3 scions/plant. The inoculated potato plants were inspected weekly for symptoms for 10 weeks after inoculation, and symptom details were recorded. After 8 to 10

TABLE 2. Systemic infections in 14 potato cultivars following sap and graft inoculation with potato virus A (PVA) isolate $\mathrm{PE}^{\mathrm{a}}$

\begin{tabular}{|c|c|c|c|c|c|c|}
\hline \multirow[b]{2}{*}{ Cultivar } & \multicolumn{2}{|c|}{ Experiment 3} & \multicolumn{2}{|c|}{ Experiment 4} & \multicolumn{2}{|c|}{ Experiment 5} \\
\hline & Sap & Graft & Sap & Graft & Sap & Grow-on \\
\hline Atlantic & $\mathrm{NI}$ & $\mathrm{NI}$ & - & - & $\mathrm{NI}$ & - \\
\hline Banana & - & - & NI & SS & SS & SS \\
\hline Coliban & NI & NI & - & - & NI & NI \\
\hline Cranberry Red & - & - & SS & SS & SS, R & SS \\
\hline Goldrush & - & - & NI & NI & NI & - \\
\hline Kennebec & - & - & NI & NI & NI & - \\
\hline King Edward & $\mathrm{NI}$ & NI & - & - & $\mathrm{NI}$ & - \\
\hline Maris Piper & NI & NI & - & - & NI & - \\
\hline Nicola & - & - & NI & NI & NI & - \\
\hline Pink Eye & - & - & SS & SS & SS & SS \\
\hline Ranger Russet & NI & NI & - & - & NI & - \\
\hline Shepody & NI & NI & - & - & NI & - \\
\hline Spunta & NI & NI & - & - & NI & - \\
\hline Tolaas & - & - & NI & NI & NI & - \\
\hline
\end{tabular}

a Potato plants were inoculated with isolate PE using infective sap (2 to 5 plants/cultivar) or grafting with infected potato scions (3 plants/cultivar). Both sap- and graft-inoculated plants were observed for symptoms for 6 to 8 weeks. Tip leaf samples were tested for PVA infection by enzyme-linked immunosorbent assay at 4 to 8 weeks postinoculation. When no virus was recovered from tip leaves, samples from the inoculated leaves were also tested. In experiment 5, three tubers were collected from an infected plant, and tip leaves were tested for PVA by ELISA. SS = symptomless systemic infection, $\mathrm{R}=$ rugosity, $\mathrm{NI}=$ not infected, and - indicates not tested. Names in bold indicate cultivars previously used as differentials (Rajamäki et al. 1998; Valkonen et al. 1995) or plants in which PVA was detected. (experiment 1) or 6 (experiment 2) weeks, plants lacking necrotic symptoms (experiment 1) or all plants (experiment 2) were tested for PVA presence by back inoculation of tip leaf samples to healthy plants of tobacco and Physalis floridana, as described by Jones (1990). PVA caused mild systemic vein banding in tobacco but obvious local necrotic spots without systemic infection in $P$. floridana. In experiments 3 and 4 , plants belonging to different potato cultivars were inoculated with isolate PE infective sap ( 2 to 5 plants/cultivar) or grafting with infected potato scions (3 plants/cultivar); the 2 U.K. cultivars used by Valkonen et al. (1995) and Rajamäki et al. (1998) (King Edward and Maris Piper) were included along with 12 other cultivars grown in Australia. Both sap- and graft-inoculated plants were observed for symptoms for 6 to 8 weeks. Tip leaf samples from the main stems (sap inoculation) or axillary shoots (graft inoculation) were tested for PVA infection by enzyme-linked immunosorbent assay (ELISA) at 4 to 8 weeks postinoculation. When no virus was recovered from tip leaves, samples from the inoculated leaves of sap inoculated plants were also tested. In experiment 5 , plants of the same 14 cultivars inoculated in experiments 3 to 4 were inoculated with isolate PE. Experiment 5 differed in that only sap inoculation was used, only two plants of each cultivar were inoculated, and tip leaf samples we tested for PVA by ELISA after 6 and 8 weeks. In addition, it also differed from experiments 3 and 4 in that, with each cultivar that gave a positive ELISA result in tip leaf testing, three tubers were collected from an infected plant and replanted. Tip leaves from their emerging shoots were tested for PVA by ELISA.

ELISA. In the United Kingdom and Australia, samples from inoculated or mock-inoculated leaves and tip leaves from biological study experiments 1 to 5 were tested for PVA using DAS-ELISA (Clark and Adams 1977). The United Kingdom samples were tested as described by Jones (1990). In Australia, the samples were extracted $(1 \mathrm{~g}$ per $20 \mathrm{ml})$ in phosphate-buffered saline $(10 \mathrm{mM}$ potassium phosphate and $150 \mathrm{mM}$ sodium chloride, $\mathrm{pH} 7.4$ ), containing Tween 20 at $5 \mathrm{ml} /$ liter and polyvinyl pyrrolidone at $20 \mathrm{~g} /$ liter using a mixer mill (Retsch, Germany). All samples were tested in duplicate wells in microtiter plates, and sap from PVA-infected and healthy leaf samples were included in paired wells as controls. The substrate was p-nitrophenyl phosphate at $0.6 \mathrm{mg} / \mathrm{ml}$ in diethanolamine, $\mathrm{pH} 9.8$, at $100 \mathrm{ml} /$ liter. A volume of $200 \mu \mathrm{l}$ was added to each well. Absorbance values $\left(\mathrm{A}_{405}\right)$ were measured in a Bio-Rad microplate reader (model 680; Bio-Sys, Australia). The polyclonal PVA antiserum used was from Agdia (United States). Positive values were always more than three times those of the negative controls. In The Netherlands, after being sent from Schipol airport to The Netherlands National Plant Protection Organization, each lot of 6 to 10 tubers was planted in a quarantine greenhouse, and a bulk leaf sample from each lot was tested for virus infection by double-antibody sandwich (DAS)-ELISA. PVA was detected in lots 4631741, 5998981 and 4631723. The only differences in the DAS-ELISA protocol used were that leaf samples were extracted $(0.7 \mathrm{~g}$ per $3.5 \mathrm{ml})$ in phosphate-buffered saline $(2.9 \mathrm{mM}$ potassium phosphate, $2.7 \mathrm{mM}$ potassium chloride, $16 \mathrm{mM}$ di-sodium hydrogen phosphate dodecahydrate, and $137 \mathrm{mM}$ sodium chloride, $\mathrm{pH}$ 7.4), albumin from bovine serum at $2.0 \mathrm{~g} /$ liter was added to the polyvinyl pyrrolidone, a hand mixer was used, and the polyclonal PVA antiserum was from Prime Diagnostics, The Netherlands.

High-throughput sequencing. In Peru, total RNA was extracted from each potato leaf sample using trizol as instructed by the manufacturer. The large RNA fraction was precipitated by adding an equal volume of $4 \mathrm{M} \mathrm{LiCl}$ at approximately $4^{\circ} \mathrm{C}$ (on ice) overnight, followed by centrifugation. The remaining small RNA fraction was subsequently precipitated by adding 1 volume of isopropanol followed by centrifugation. Small RNAs were separated on $3.5 \%$ agarose gels and bands corresponding to approximately 20 to $25 \mathrm{nt}$ were excised and purified using quantum prep freeze and squeeze columns (Bio-Rad). Small RNA libraries were prepared using the protocol of Chen et al. (2012) and sent for sequencing on a HiSeq4000 by a commercial provider (Fasteris Life Sciences SA, Switzerland). Small RNA sequences were analyzed using 
VirusDetect v1.6 (Zheng et al. 2017) to identify all viruses infecting the plants, and samples in which PVA was identified were selected for further analysis. Using the Geneious R11.1.3 software package, the PVA contigs produced by VirusDetect were extracted for each positive sample and a consensus generated. The small RNAs were then mapped back to the consensus to confirm the quality of the assemblies and make any corrections as necessary. The new genomic sequences with complete open reading frames (ORFs) were mostly $9,180 \mathrm{nt}$ long, with a few 9,014 nt long. Final nucleotide sequences of the 32 isolates with complete ORFs were submitted to GenBank with accession codes MT502351 to MT502382 (Table 1).

In the United Kingdom, samples of freeze-dried PVA-infected leaf material containing one each of 11 isolates (GW, PE, 22, 608, $613,622,775$, HER, MAR, 9C, and 14D) were subjected to highthroughput sequencing in 2016 to 2019 (Table 1). Total RNA was extracted from each sample using the Total RNA kit (Qiagen, U.K.), including the optional DNAase treatment. An indexed sequencing library was produced from the total RNA using a Scriptseq complete plant leaf kit (Illumina, U.S.A.) and sequenced on a MiSeq instrument (Illumina), using a 600-cycle V3 kit. The methods followed are described in more detail by Fox et al. (2019). All isolates except 608 provided a complete PVA ORF. No other virus sequences were associated with the complete ORFs, except with isolates 613 (PVV sequence present) and KIP (PVY and potato virus $\mathrm{S}$ [PVS] [genus Carlavirus, family Betaflexiviridae]) sequences present). The 10 new genomic sequences with complete ORFs obtained were mostly 9,180 nt long. Final nucleotide sequences of the 10 isolates with complete ORF were submitted to GenBank with accession codes MT435485 to MT435488 and MT435490 to MT435495 (Table 1).

In The Netherlands, total RNA was extracted from bulked potato leaf samples 4631741, 5998981, and 4631723, as described by Botermans et al. (2013). RNA extracts were DNAse treated and sent to GenomeScan (Leiden, The Netherlands) for generation of $2 \mathrm{~Gb}$ of Illumina RNAseq 150PE (paired-end) data per sample. Sequencing was done on an Illumina NovaSeq (Illumina). RNAseq data were analyzed in CLC Genomics workbench v11.0.1 (Qiagen, Germany) and run in a custom workflow built for detection of de novo assembled viral contigs. These contigs ( $>100 \mathrm{nt}$ ) were analyzed using BLASTn and DIAMOND (Buchfink et al. 2015) with the NCBI $\mathrm{nr}(/ \mathrm{nt}$ ) databases. Blast results were visualized in Krona (bit score threshold = 25) (Ondov et al. 2011). Viral sequences were analyzed using Geneious R11 (Biomatters, New Zealand). The three new genomic PVA sequences with complete ORFs obtained were 9,545 to 9,549 nt long. Final nucleotide sequences with complete ORFs were submitted to GenBank with accession codes MT521081 to MT521083 (Table 1).

In Australia, with isolate KIP, approximately $30 \mu \mathrm{l}$ of total RNA was retrieved from storage at $-80^{\circ} \mathrm{C}$ from a previous study (Kehoe and Jones 2011) and the total RNA extract was sent to the Australian Genome Research Facility for library preparation and barcoding (24 samples/lane) before 100-bp single-end sequencing on an Illumina HiSeq2000. The reads obtained were processed as described by Kehoe and Jones (2016). Its complete ORF was
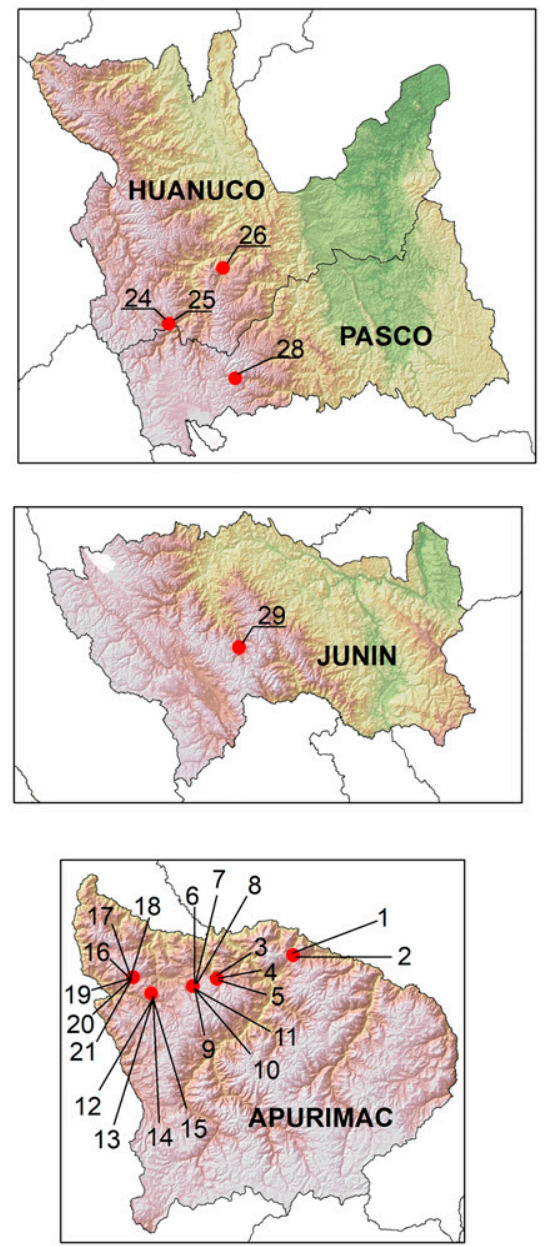
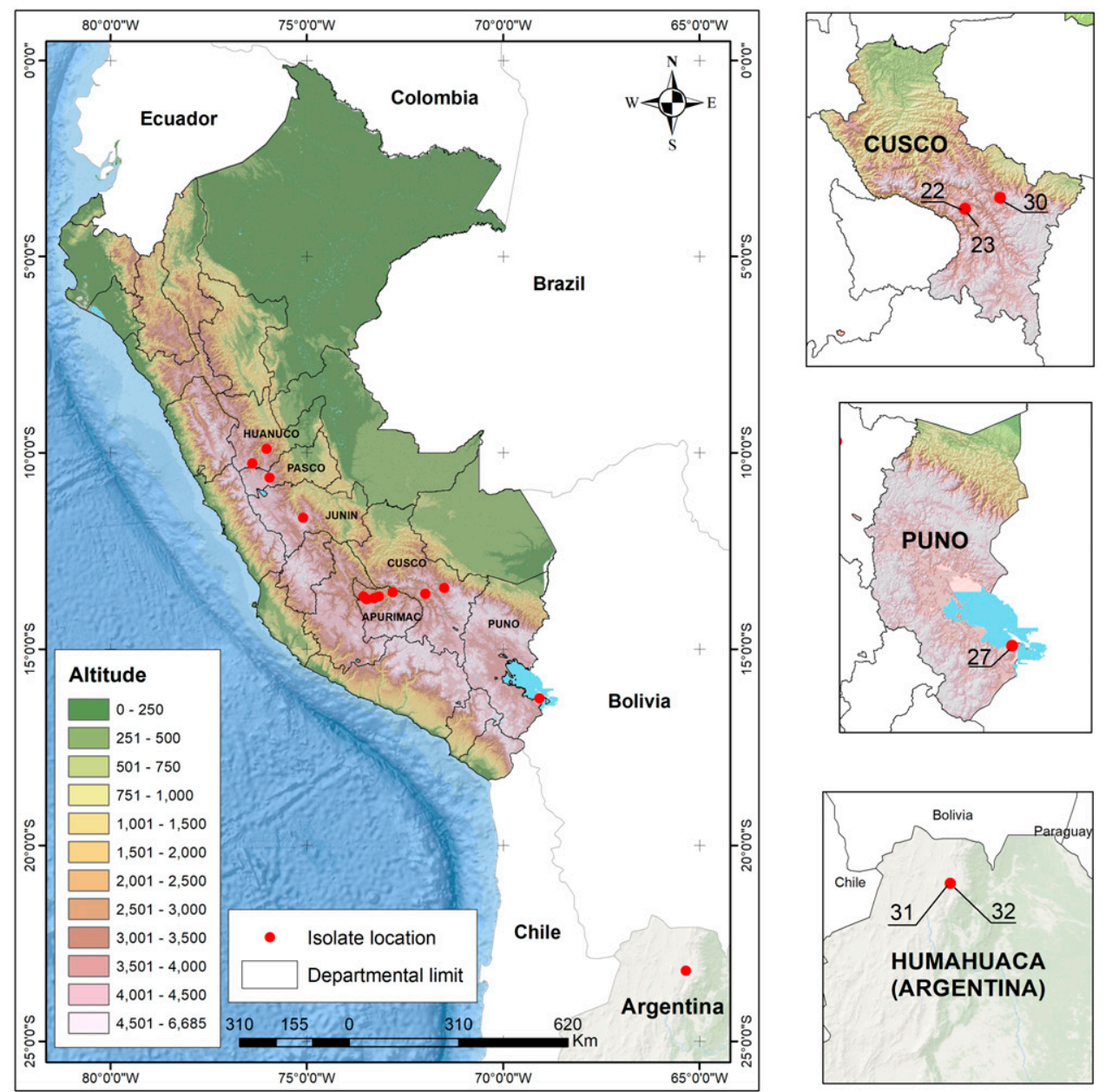

Fig. 1. Map of sample collection sites in the Andean Highlands showing where potato virus A-infected potato samples were obtained. Dots marked on the main map represent the locations sampled and the names marked on it are those of the countries regional departments sampled (black lines are departmental boundaries). Dots marked on the individual department maps clustered on either side show each collection site, and the numbers indicate each individual infected sample collected. The bottom right corner shows the location in the province of Jujuy where the two numbered Argentine samples were collected. 
9,180 nt long. The final nucleotide sequence was submitted to GenBank with accession code MT435489 (Table 1).

Sequence analysis. New $(n=46)$ and downloaded $(n=17)$ sequences were edited using BioEdit (Hall 1999) to extract the ORFs $(n=63)$ or their CP genes (including 26 others). These were aligned, using the encoded amino acids as guide, by the TranslatorX online server (Abascal et al. 2010) (http://translatorx.co.uk) with its MAFFT option (Katoh and Standley 2013). To search for non-PVA sequences with which to compare and root phylogenies, the BlastN online facilities of GenBank (Altschul et al. 1990) were used with the sequences representing the basal divergences of the phylogeny (i.e., the most distantly related PVAs). Sequences were tested for the presence of phylogenetic anomalies using the full suite of options in RDP4 with default parameters (Boni et al. 2007; Gibbs et al. 2000; Holmes et al. 1999; Lemey et al. 2009; Martin and Rybicki 2000; Martin et al. 2005, 2015; Maynard-Smith 1992; McGuire and Wright 2000; Padidam et al. 1999; Posada and Crandall 2001); anomalies found by fewer than four methods and with $>10^{-5}$ random probability were ignored. Phylogenetic trees were calculated using the neighbor-joining option in ClustalX (Jeanmougin et al. 1998), and PhyML 3.0 (ML) (Guindon and Gascuel 2003). In PhyML, the statistical support for their topologies was assessed using the SH method (Shimodaira and Hasegawa 1999). The temporal signal in alignments of dated nonrecombinant ORFs was assessed using TempEst v 1.5 (Rambaut et al. 2016). Trees were drawn using Figtree, version 1.3 (http://tree.bio.ed.ac.uk/software/ figtree/) and a commercial graphics package. The positions of basal nodes of subtrees in ML phylogenies (Hajizadeh et al. 2019; Mohammadi et al. 2018) were compared using PATRISTIC (Fourment and Gibbs 2006). This converts tree files to matrices of their pairwise patristic distances that can then be interrogated using MS Excel; the mean pairwise patristic distance between all tips connected through each selected basal node is calculated. PATRISTIC was also used to check for mutational saturation by comparing the patristic distances of the nucleotide phylogenies with those of the amino acids they encoded.

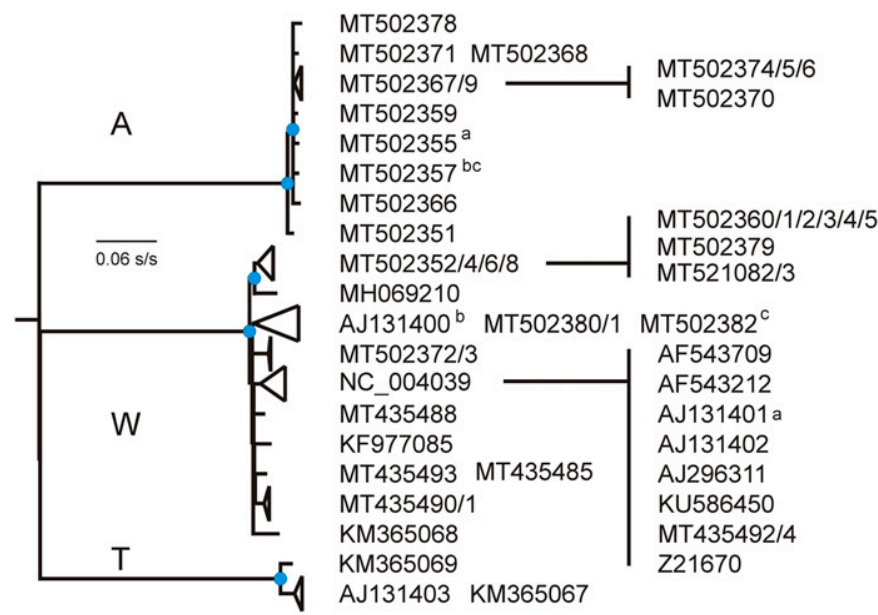

Fig. 2. Maximum-likelihood phylogeny of the 54 full-length potato virus A open reading frames compared. It was midpoint rooted and a potato yellow blotch virus root came from the same edge. All terminal clusters with complete statistical support (SH 1.0) are collapsed, and the accession numbers of their sequences are shown. Dots indicate all other nodes with $>0.95 \mathrm{SH}$ support. Three major phylogroups are present: $\mathrm{A}=$ isolates only from the Andes, $\mathrm{W}=$ from the world, including the Andes, and $\mathrm{T}=$ from tamarillo (Solanum betaceum). A cluster of seven closely related recombinants and two unique recombinants was found by RDP analysis. All had major parents from the W lineage and minor parents from the $\mathrm{P}$ lineage. They were omitted from the phylogeny. Their nearest parental sequences are marked with the suffixes $a, b$, and $\mathrm{c}$.

\section{RESULTS}

Biological studies. In experiment 1 , the axillary shoots of the graft-inoculated King Edward plants developed severe or less severe necrotic phenotypes with isolates 775 and 622 , respectively, but not with isolates 608 or 613 , which developed fully susceptible phenotypes. Similar phenotypes were obtained in experiment 2 , but all three isolates included $(608,613$, and 622) elicited somewhat milder symptoms than in experiment 1 . Overall, the predominant symptoms caused by isolate 775 were systemic chlorotic blotching, chlorotic blotchy mottle, and leaf deformation, followed by leaf drop, necrotic spotting, apical necrosis, and shoot death. Those caused by isolate 622 were systemic chlorotic blotching, necrotic stem streaking, veinal necrosis, and apical necrosis. Isolates 608 and 613 caused mild chlorotic blotching and chlorotic blotchy mottle. Back-inoculation of tip leaf samples without necrosis to indicator hosts confirmed the presence of PVA in plants inoculated with isolates 608,613 , and 622 . These findings are consistent with those of PVA isolates belonging to PVA strain groups 1 (isolate 775) and 2 (isolates 608,613 ). Although the systemic necrosis elicited by infection with isolate 622 was less severe than with isolate 775 , its symptomatology was also closest to that of strain group 1 in King Edward. Also, the symptomatology obtained with isolate 613 was closest to strain group 2 despite PVV also being found when it was sequenced and PVV hypersensitivity gene $N v$ being present in King Edward (Jones 1990). PVV isolates normally elicit a hypersensitive (necrotic) phenotype in the presence of $N v$, which did not occur in this instance.

In experiments 3 to 5, ELISA testing of tip leaf samples found systemic infection with isolate PE after sap and graft inoculation in three cultivars: Banana, Cranberry Red, and Pink Eye (Table 2). Infection was symptomless in all instances, except in Cranberry Red, which developed leaf rugosity. No infection occurred in plants of key PVA strain group differential King Edward or in any of the other nine cultivars inoculated, including Maris Piper. These findings with isolate PE are consistent with those of isolates belonging to PVA strain group 3.

Phylogenetics. The 46 ORFs from the PVA sequences reported in this article, together with the 17 downloaded from GenBank, produced an alignment of 63 sequences $9,180 \mathrm{nt}$ in length. They were checked for evidence of recombination using the RDP suite of programs, and nine were found to be recombinant (Supplementary Table S1). The 54 nonrecombinant ORFs were used to calculate an ML tree (Fig. 2). The sequences formed three tight phylogroups on long branches. One was a phylogroup of 14 ORFs, all reported first in this article and from the Peruvian Andean region of South America, mostly from its Apurimac Department; 10 of them were isolated from native potato land races consisting of triploids (Solanum $\times$ chaucha), two diploids $(S$. stenotomum), and one tetraploid (S. tuberosum subsp. andigena); and 1 from a locally bred tetraploid cultivar ( $S$. tuberosum subsp. tuberosum $\times$ andigena) (Table 1). The second and largest phylogroup was of 37 ORFs from isolates from several potato-growing regions of the world, including several directly from Peruvian land races in the Andean region, seven of the new sequences from Europe (MT435485, MT435488, MT435490, MT435491, MT435492, MT435493, and MT435494) and four from other Andean land races, two each from Argentina (MT502381 and MT502382) and airport interceptions in The Netherlands (MT521082 and MT521083). The third phylogroup was of three isolates from tamarillo plants (S. betaceum) growing in New Zealand. We call these three the A (Andean), W (World), and T (Tamarillo) phylogroups, respectively (Fig. 2). The most different PVA sequences (i.e., those with minimum percent nucleotide identity) were the T phylogroup sequence AJ131403 and the A phylogroup sequence MT502355, and these had $82.3 \%$ identity.

The nine recombinant isolates (Supplementary Table S1) consisted of one group of seven isolates collected on three continents but the progeny of a single recombination event (W/A1), and two 
other unique recombinants (W/A2 and W/A3), both of which were isolated in Peru. All recombinants had major "parents" from the W phylogroup and minor parents from the A phylogroup, and these parental sequences are marked with the suffixes a, b, and c in Figure 2. The large group (W/A1: GU144321, MT435486/7/9, MT435495, MT502377, and MT521081) had a major parent closest to AJ131402a and minor closest to MT502355a (nucleotides 8,792 to 8,892); the nearest parents to recombinant MT502353 (W/A2) were AJ131400b and MT502357b (nucleotides 2,660 to 3,028) and to recombinant MT502380 (W/A3) were MT502382c and MT502357c (nucleotides 6,784 to 6,826 ). Because the five W/A1 recombinants from outside the Andes had phylogroup A as a minor parent, either these arose recently in the Andes and were carried elsewhere or there is a phylogroup A population outside the Andes but as yet undetected there.

An additional 26 partial PVA sequences in the GenBank database contained CP genes; therefore, these were added to those from the complete genomes, aligned, and used to calculate an ML phylogeny. This had the same three phylogroups as those in the phylogeny of the complete ORFs (data not shown), and all of the additional CP sequences joined the $\mathrm{W}$ phylogroup, except two that joined the $\mathrm{T}$ phylogroup and came from tamarillo in New Zealand. The GenBank records of the complete $\mathrm{W}$ phylogroup $\mathrm{CP}$ genes showed that the additional ones came from potato in China, the United Kingdom (Scotland), India, Iran, Switzerland, and Tanzania. The absence of phylogroup A among these 26 partial sequences is consistent with its apparent absence outside the Andes.

Searches of the GenBank database with the ORF of the PVA type sequence (NC_004039), and with its encoded protein sequence, confirmed that PYBV is the virus most similar to but still distinct from PVA (Gibbs et al. 2020) (sequence identity $=74.4 \%$ nucleotides and $77.4 \%$ amino acids), and both are members of the tobacco etch virus (TEV) lineage. An ML phylogeny of the aligned ORFs of the nine distinct viruses of the TEV lineage that were found is shown in Figure 3.

Dating. No temporal signal was detected in alignments of the dated nonrecombinant PVA ORFs using TempEst (Rambaut et al. 2016). Therefore, the approximate dates of selected nodes in the phylogeny of PVA were estimated by the subtree comparison method described by Mohammadi et al. (2018) and Hajizadeh et al. (2019). This requires an ML phylogeny including PVA and PVY sequences representing the basal divergences of the PVA-A, PVA-W, and PVA$\mathrm{T}$ phylogroups, and the sequences that represent the basal divergences of the PVY-N and PVY-O phylogroups and the PVY Chile 3 sequence (Gibbs et al. 2017). In this way, the phylogenetic diversities of the PVA and PVY phylogenies were compared within the same ML phylogeny (Fig. 3), and can be seen to be similar in "height" (i.e., tips to roots). The mean pairwise patristic distance of tips connected through the root of the PVA subtree in Figure 3 is $0.0 .2737 \pm 0.007$ substitutions per site $(\mathrm{s} / \mathrm{s})$ and of PVY is $0.2751 \pm$ $0.037 \mathrm{~s} / \mathrm{s}$, indicating that these viruses first invaded potato at approximately the same time. Fuentes et al. (2019) estimated that PVY invaded potato crops in approximately $156 \mathrm{CE}$ using the Bayesian tip-dating method with two models (Drummond et al. 2012), and the mean date from three similar estimates by Gao et al. (in press) was $158 \mathrm{CE}$. Thus, using a mean PVY date of $157 \mathrm{CE}$, a simple arithmetic comparison of the patristic distances and dates indicates that the TMRCA of the PVA population is approximately $166 \mathrm{CE}$ $(1,854$ years before the present [YBP] $)$, with a mean coefficient of variation of the patristic distances of 0.080 .

Additional comparisons were made in which the number of PVA, PVY, and outgroup sequences were varied to assess how much the estimated dates were affected. The minimum number of PVA and PVY sequences required to define their basal divergences are six and five, respectively. When these were used together with the same 22 outgroup sequences, the PVA/PVY TMRCA ratio was 0.961 , with a mean coefficient of variation of 0.093 . When 11 PVA sequences and $10 \mathrm{PVY}$ sequences were used, the PVA/PVY TMRCA ratio was 0.929 , with the same coefficient of variation. Removing all outgroup sequences gave a PVA/PVY TMRCA ratio of 1.037 but with a 10-fold larger coefficient of variation (0.795). These tests indicate that the PVATMRCA estimated by this simple method ranged from 166 to $289 \mathrm{CE}$ (approximately 6.6\%).

These TMRCAs for the PVA population were then used to date the TMRCAs of the PVA phylogroups in Figure 2. The mean pairwise patristic distance of the basal node of the phylogeny was $0.494 \mathrm{~s} / \mathrm{s}$ $( \pm 0.016)$ and of the $\mathrm{A}, \mathrm{W}$, and T phylogroups was $0.014 \mathrm{~s} / \mathrm{s}( \pm 0.002)$, $0.040 \mathrm{~s} / \mathrm{s}( \pm 0.009)$, and $0.031 \mathrm{~s} / \mathrm{s}( \pm 0.003)$, respectively. Using PVA TMRCAs of 166 or $289 \mathrm{CE}$, these translate to the A phylogroup having a TMRCA of 1967 or $1971 \mathrm{CE}$, the W phylogroup of 1870 or $1880 \mathrm{CE}$, and the T phylogroup of 1904 or $1911 \mathrm{CE}$.

\section{DISCUSSION}

This study constitutes the third of three related studies comparing the properties of isolates of three common potato viruses (PVA, PVY, and PVS) from the center of origin of the potato crop in the Andean region of South America with those of isolates from elsewhere in the world, and making deductions about their prehistory (Fuentes et al. 2019; Santillan et al. 2018). With all three viruses, phylogenetic analysis of nonrecombinant genomic sequences from the Andes revealed greater diversity there than occurred elsewhere. With PVA, this included the discovery of a previously unknown phylogroup consisting solely of potato isolates from the Peruvian Andean region, another with potato isolates from the Andes and elsewhere in the world, and a third with solely nonpotato isolates. The TMRCA for the entire PVA population was estimated at approximately $165 \mathrm{CE}$, closely similar to that of PVY.

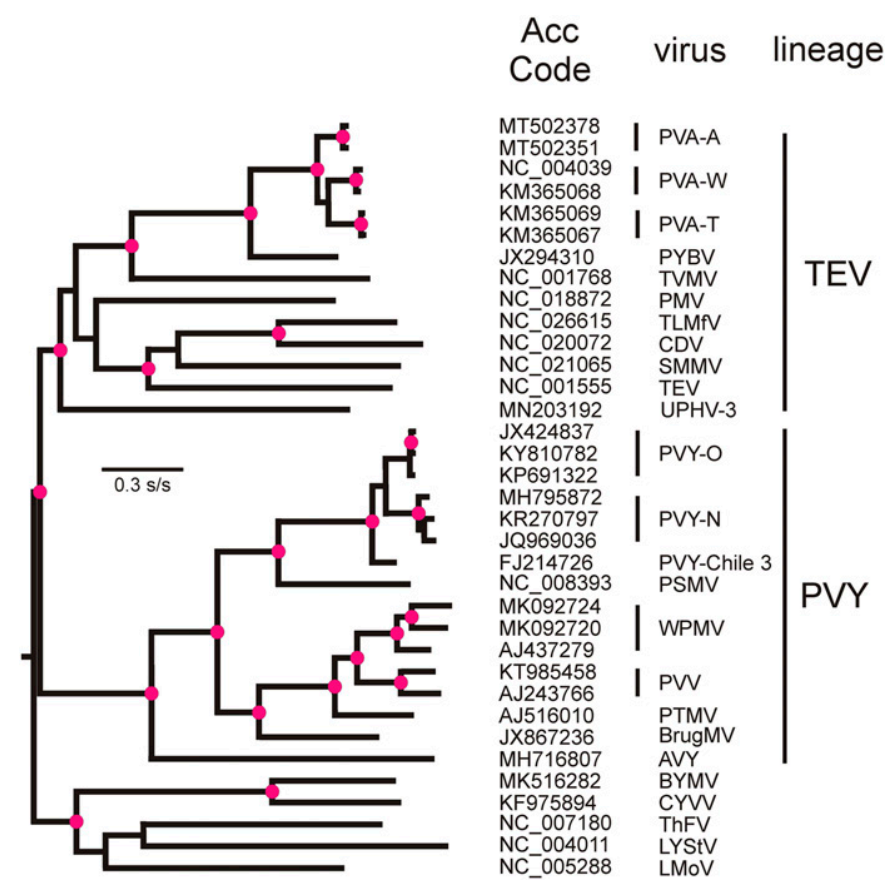

Fig. 3. Maximum-likelihood phylogeny of the open reading frames of the tobacco etch virus (TEV) lineage of potyviruses, together with that of a selection of potato virus Y (PVY) lineage and outgroup potyviruses. Nodes with a dot are those with $>0.95 \mathrm{SH}$ support; most other nodes have $\mathrm{SH} 1.0$ statistical support. Virus acronyms are AVY = arracacha virus $\mathrm{Y}, \mathrm{BrugMV}=\mathrm{Brugmansia}$ mosaic virus, BYMV = bean yellow mosaic virus, $\mathrm{CDV}=$ Colombia datura virus, $\mathrm{CYVV}=$ clover yellow vein virus, $\mathrm{LMoV}=$ lily mottle virus, $\mathrm{LYStV}=$ leek yellow streak virus, PMV = pokeweed mosaic virus, PSMV = pepper severe mosaic virus, PTMV = Peru tomato virus-PDK11, PVA-A = potato virus $\mathrm{A}-\mathrm{A}, \mathrm{PVA}-\mathrm{T}=$ potato virus $\mathrm{A}-\mathrm{T}, \mathrm{PVA}-\mathrm{W}=$ potato virus $\mathrm{A}-\mathrm{W}, \mathrm{PVV}=$ potato virus V, PVY-Chile 3 = potato virus-Chile 3 , PVY-N = potato virus $\mathrm{Y}-\mathrm{N}$, $\mathrm{PVY}-\mathrm{O}=$ potato virus $\mathrm{Y}-\mathrm{O}, \mathrm{PYBV}=$ potato yellow blotch virus, SMMV = sunflower mild mosaic virus, $\mathrm{TEV}=$ tobacco etch virus, $\mathrm{ThFV}=$ Thunberg fritillary virus, TLMfV = tamarillo leaf malformation virus, TVMV = tobacco vein mottling virus, UPHV-3 = UPHV-3 metagenome, and WPMV $=$ wild potato mosaic virus. 
PVA's phylogroup W, like the PVYO phylogroup, apparently commenced a large divergence in approximately $1870 \mathrm{CE}$. Its phylogroup A apparently started a similar divergence in the Andean region in approximately 1967 CE; PVA recombinants between phylogroups A and W isolates apparently first appeared at much the same time. Three of PVA's four biological strain groups, none of which were in phylogroup A, were among five isolates characterized biologically.

In our biological studies, graft inoculation of King Edward caused systemic necrosis with isolates 622 and 775 (typical of PVA1), mottle with isolates 608 and 613 (typical of PVA-2), or no infection with isolate PE (typical of PVA-3). With isolate 622, the systemic necrosis induced was less severe than with 775 but its presence excluded membership of other strain groups. Isolates in strain group 1 but not those in strain group 2 elicit a necrotic phenotype in plants with the hypersensitivity gene $N a_{K E}$, which explains the different phenotypes obtained. Additional evidence for isolate PE's membership of PVA-3 comes from the responses of other cultivars graft inoculated with it. When Rajamäki et al. (1998) graft inoculated 21 PVA isolates to plants of Maris Piper potato, two of their isolates failed to infect it, which resembled the results that Valkonen et al. (1995) obtained with their PVA-3 isolate and we obtained with isolate PE. Moreover, isolate PE's failure to infect 11 of the 14 cultivars inoculated with it resembled the failure of Valkonen et al. (1995)'s PVA-3 isolate to infect 7 of 8 cultivars. It was also clear that the current biological strain groupings do not correlate with the phylogenetic grouping of the PVA isolates because all those discussed above are from the $\mathrm{W}$ phylogroup, or are recombinants with a major $\mathrm{W}$ phylogroup parent (isolate $\mathrm{PE}$ ), with phylogroup $\mathrm{A}$ and $\mathrm{T}$ isolates yet to be tested. In a separate study, when eight different PVA isolates from wild potato species in Peru were inoculated to plants of nine potato cultivars, including King Edward, they belonged to strain groups 2 and 3 (De la Torre 2006). Further research is needed to establish whether the PVA strain group situation in Peru, and elsewhere in the center of origin of the potato crop, resembles that occurring elsewhere.

Our phylogenetic analyses of nonrecombinant PVA genomes found that the three distinct PVA phylogroups form three tight groupings on long branches (Fig. 2), which is a topology perhaps indicating that PVA has mostly survived until recently as small populations (Hughes 2009). One of them, the Andean (A) phylogroup, is mostly from triploid native potato land races. The much larger world (W) phylogroup is of many South American isolates, including some from Andean land races and many from other parts of the world. The third phylogroup (T) is of three isolates from tamarillo in New Zealand, where it has been grown since the end of the 19th century (Prohens and Nuez 2001). There have been several unconfirmed reports of PVA and other potyviruses being isolated from tamarillo in Colombia (Duque Villegas et al. 2017; Gutiérrez et al. 2015; Insuasti et al. 2016; Jaramillo et al. 2011) but there is limited gene sequence evidence of this.

We have confirmed that PVA, like PVY, is a potyvirus of the Americas (Fuentes et al. 2019). However, unlike PVY, it belongs to the TEV lineage (Fig. 3). GenBank now includes the full-length genomes of eight other distinct members of this lineage, including a metagenome (UPHV-3) isolated from "weeds" in a papaya orchard in the Chiapas region of Mexico (Alcalá-Briseño et al. 2020). Six of the TEV lineage members have only been reported from the Americas; two (PVA and Colombian datura virus) have been reported from elsewhere, too; and one, potato yellow blotch virus, only from a potato breeding line in Scotland, United Kingdom (Nisbet et al. 2019), has thus far only been found outside the Americas. Interestingly, the TEV lineage shares several properties with the PVY lineage, which is of at least 27 viruses ( 18 found only in the Americas, 7 worldwide, and only 2 not yet found in the Americas) (Fribourg et al. 2019). The primary (field) hosts of both lineages are mostly from the asterid clade of angiosperms, and both include members that infect sunflower (Helianthus annuus) (Haston et al. 2009).
We could not date the PVA phylogeny directly because the dated sequences gave no evidence of a temporal signal. However, we dated the PVA phylogeny comparatively using the well-established TMRCA of 157 CE for PVY, and ML phylogenies that included both PVA and PVY sequences. Such "subtree datings" will inevitably be less accurate than those estimated directly but they can still usefully help interpret phylogenies if both the primary and derived datings are checked against, and coincide with, independent historical events. For example, subtree dating was devised and used by Mohammadi et al. (2018) to determine whether the beet mosaic potyvirus (BtMV) now found worldwide in sugar beet crops was a virus that had emerged since the sugar beet crop had been developed during the past three centuries, or whether it was derived from a multiple "spillover" infection from an ancient virus population in leaf beet (chard), which has been cultivated for at least two millennia. Using the best dates for PVY and turnip mosaic virus (genus Potyvirus) then available, they found that all available BtMV sequences formed a single population only 360 years old (range 260 to 490 years) and, therefore, likely emerged during the development of sugar beet as a crop over the past three centuries, probably from wild (sea) beet (Beta vulgaris subsp. maritima), which is the wild ancestor of all cultivated beet (Biancardi et al. 2012).

The subtree comparison of PVA and PVY is likely to be more accurate than those of BtMV and plum pox virus (genus Potyvirus) (Mohammadi et al. 2018; Hajizadeh et al. 2019) because PVA and PVY infect the same host and have the same vectors. Furthermore, the similarity of the estimated TMRCAs for the PVA population (166 to $289 \mathrm{CE}$ ) and the PVY population (157 CE) suggests that they infected potato at least as early as the beginning of Tiahuanaco era in the Lake Titicaca region, when potato cropping expanded within Bolivia and southern Peru. That era lasted from 110 to $300 \mathrm{CE}$ (early formative period) and then from 300 to approximately $1000 \mathrm{CE}$, when the Tiahuanaco empire eventually ended (Browman 1978; Hawkes 1978, 1990). The phylogenies of both viruses show a large radiation that probably occurred after they were taken to Europe by the Spaniards who had invaded the Andean region. This large radiation of PVA's phylogroup W seems to have occurred in approximately 1870 to 1880 $\mathrm{CE}$, matching the large radiation of the European $\mathrm{PVYO}$ phylogroup in approximately $1868 \mathrm{CE}$ and indicating that they likely had a common cause. This adds weight to the suggestion of Fuentes et al. (2019) that the PVYO radiation was a sequel to the epidemics of potato late blight (Phytophthora infestans) in European potato crops in 1845 to 1849 CE (Donnelly 2002; Zadoks 2008). Blight ruined most European potato crops because the cultivars being grown were inbred and susceptible (Glendinning 1983). As a result, new cultivars were bred using the few survivors of the blight epidemics and potato germplasm imported from South America. International trade in potato, and the viruses they carried, was greatly stimulated, resulting in the radiations now seen in the PVA and PVY phylogenies (Fuentes et al. 2019).

The radiation of PVA phylogroup A was clearly more recent than that of the W phylogroup, and was estimated to have occurred approximately 1967 to 1971 CE. Interestingly, this coincides with the release in 1966 of Ticahuhasi potato, the first of the series of locally bred potato cultivars that involved crossing $S$. tuberosum subsp. tuberosum with $S$. tuberosum subsp. andigena. These cultivars were developed by the Peruvian National Potato Breeding Program (De Erratus 1974; Franco 1994; French 1972; SeminarioCunya, 2008). Their rapid dissemination resulted in widespread intermingling between potato land races and newly bred cultivars within Andean smallholder plantings, and this may have resulted in the major divergence of the A phylogroup. In addition, this intermingling would have provided the opportunity for mixed infections of $\mathrm{A}$ and $\mathrm{W}$ phylogroup isolates to generate the recombinants we found; phylogroup $\mathrm{W}$ was probably introduced to the Andean region by the $S$. tuberosum subsp. tuberosum germplasm used as parental material for the newly bred cultivars. Finally, the $\mathrm{T}$ phylogroup is a consistently separate biological strain 
thus far only found in tamarillo; therefore, a combination of biological and genetic information may indicate that it is better to consider it a separate virus species (Adams et al. 2005).

Finally, the datings in Figure 3 may also be extrapolated even further back in time, first to the divergence of PVA from PYBV at approximately 4,965 to 4,636 years ago, which is consistent with the start of potato domestication approximately 9,000 to 7,000 years ago (Fuentes et al. 2019). They may also be extrapolated back even further, to the basal nodes of the TEV and PVY lineages, approximately 15,340 to 14,148 and 14,200 to 13,251 years ago, respectively, where their basal nodes branch from lineages dominated by potyviruses isolated in the Old World (Gibbs et al. 2020). The period 15,300 to 14,200 YBP, which includes the PVA and PVY basal dates, is when lower sea levels had exposed Beringia, an area of land joining Asia and North America, allowing Asian organisms to spread through the steppe to the Americas. These dates are important for timing purposes because the biological connection between Asia and the Americas was from approximately 17,000 YBP, when the Last Glacial Maximum had receded sufficiently to allow organisms to spread, and finished sharply at 11,700 YBP, which was when sea levels rose quickly and inundated Beringia at the start of the Holocene (Elias et al. 1996; Waters 2019). Thus, over a large time scale, from decades to millennia, there is a plausible correspondence between features of the phylogenies of both PVA and PVY, and dated historical and prehistorical events.

The new information we have obtained about what has recently become one of the more neglected of the common potato viruses has implications for potato industries worldwide. An important practical conclusion from our study of PVA is that only one of its three main phylogroups has influenced potato's acceptance as a major food crop outside the Andean region. The $\mathrm{A} \times \mathrm{W}$ recombinant isolates were recovered from three continents (South America, Europe, and Australia), suggesting that recombinant PVA isolates are becoming widely distributed. Given the rapid population shift favoring damaging PVY recombinants witnessed in Europe and the Americas (Karasev and Gray 2013), further research is required to ascertain the potential plant health risk posed by recombinant PVA isolates. Until the biological properties and economic significance of phylogroup $\mathrm{A}$ and $\mathrm{A} \times \mathrm{W}$ recombinant isolates have been studied thoroughly, and detailed surveillance done to establish their occurrence, the plant biosecurity and quarantine organizations of non-Andean region countries should consider adopting precautions that prevent their establishment.

\section{ACKNOWLEDGMENTS}

In addition to those mentioned in the text and Table 1 who supplied PVA isolates, we thank A. Perez, P. Chavez, and M. Amao for technical support at CIP; and C. Fribourg at Universidad Nacional Agraria La Molina for advice concerning the history of potato cultivation in Peru.

\section{LITERATURE CITED}

Abascal, F., Zardoya, R., and Telford, M. J. 2010. TranslatorX: Multiple alignment of nucleotide sequences guided by amino acid translations. Nucleic Acids Res. 38:W7-W13.

Adams, M. J., Antoniw, J. F., and Fauquet, C. M. 2005. Molecular criteria for genus and species discrimination within the family Potyviridae. Arch. Virol. 150:459-479.

Alcalá-Briseño, R. I., Casarrubias-Castillo, K., López-Ley, D., Garrett, K. A., and Silva-Rosales, L. 2020. Network analysis of the papaya orchard virome from two agroecological regions of Chiapas, Mexico. mSystems 5:e00423-19.

Altschul, S. F., Gish, W., Miller, W., Myers, E. W., and Lipman, D. J. 1990. Basic local alignment search tool. J. Mol. Biol. 215:403-410.

Bald, J. G., and Pugsley, A. T. 1941. The main virus diseases of the potato in Victoria. Commonwealth Scientific and Industrial Research Organisation (CSIRO), Australia, Pamphlet No. 110.

Bartels, R. 1971. Potato virus A. Description No. 54. In: Descriptions of Plant Viruses. Commonwealth Mycological Institute/Association of Applied Biologists, Wellesbourne, U.K.

Bawden, F. C., and Sheffield, F. M. L. 1944. The relationships of some viruses causing necrotic diseases of the potato. Ann. Appl. Biol. 31:33-40.
Biancardi, E., Panella, L. W., and Lewellen, R. T. 2012. Beta maritima: The Origin of Beets. Springer, New York, NY, U.S.A.

Boni, M. F., Posada, D., and Feldman, M. W. 2007. An exact nonparametric method for inferring mosaic structure in sequence triplets. Genetics 176: 1035-1047.

Botermans, M., van de Vossenberg, B. T., Verhoeven, J. T., Roenhorst, J. W., Hooftman, M., Dekter, R., and Meekes, E. T. M. 2013. Development and validation of a real-time RT-PCR assay for generic detection of pospiviroids. J. Virol. Methods 187:43-50.

Browman, D. L. 1978. Toward the development of the Tiahuanaco (Tiwanaku) state. Pages 327-350 in: Advances in Andean Archaeology. D. L. Browman, ed. Mouton Publishers, The Hague, The Netherlands.

Buchfink, B., Xie, C., and Huson, D. H. 2015. Fast and sensitive protein alignment using DIAMOND. Nat. Methods 12:59-60.

Chen, Y., Zheng, Y., Liu, B., Zhong, S., Giovannoni, J., and Fei, Z. 2012. A cost-effective method for Illumina small RNA-Seq library preparation using T4 RNA ligase 1 adenylated adapters. Plant Methods 8:41-45.

Clark, M. F., and Adams, A. N. 1977. Characteristics of the microplate method of enzyme-linked immunosorbent assay for the detection of plant viruses. J. Gen. Virol. 34:475-483.

Clinch, P., Loughnane, J. B., and Murphy, P. A. 1936. A study of the aucuba or yellow mosaics of potato. Sci. Proc. R. Dublin Soc. 21:431.

Cockerham, G. 1943. The reactions of potato varieties to viruses X, A, B and C. Ann. Appl. Biol. 30:338-344.

Cockerham, G. 1970. Genetical studies on resistance to potato viruses X and Y. Heredity 25:309-348.

de Bokx, J. A., and van der Want, J. P. H., eds. 1987. Viruses of Potatoes and Seed-Potato Production, 2nd ed. Centre for Agricultural Publishing and Documentation, Wageningen, The Netherlands.

De Erratus, F. E. 1974. Catalogo de Semilla Basica de Papa en el Peru. INIA, CIP and COTESU, Lima, Peru.

De la Torre, C. M. 2006. Análisis de la variabilidad del virus A de la papa (PVA). Tesis Biología. Universidad Nacional Agraria La Molina, Lima, Perú.

Donnelly, J. S. 2002. Great Irish Potato Famine. The History Press, Dublin, Ireland.

Drummond, A. J., Suchard, M. A., Xie, D., and Rambaut, A. 2012. Bayesian phylogenetics with BEAUti and the BEAST 1.7. Mol. Biol. Evol. 29:1969-1973.

Duque Villegas, M., Marín Montoya, M., and Gutiérrez, P. A. 2017. Genome comparison and primer design for detection of Tamarillo leaf malformation virus (TaLMV). Arch. Phytopathol. Plant Prot. 50:713-726.

Eagles, R. M., Gardner, R. C., and Forster, R. L. 1990. Nucleotide sequence of the tamarillo mosaic virus coat protein gene. Nucleic Acids Res. 18:7166.

Eagles, R. M., Gardner, R. C., and Forster, R. L. 1994. Incidence and distribution of six viruses infecting tamarillo (Cyphomandra betacea) in New Zealand. N. Z. J. Crop Hortic. Sci. 22:453-458.

Elias, S. A., Short, S. K., Nelson, C. H., and Birks, H. H. 1996. Life and times of the Bering land bridge. Nature 382:60-63.

Fourment, M., and Gibbs, M. J. 2006. PATRISTIC: A program for calculating patristic distances and graphically comparing the components of genetic change. BMC Evol. Biol. 6:1.

Fox, A., Fowkes, A. R., Skelton, A., Harju, V., Buxton-Kirk, A., Kelly, M., Forde, S. M. D., Pufal, H., Conyers, C., Ward, R., and Weekes, R. 2019. Using highthroughput sequencing in support of a plant health outbreak reveals novel viruses in Ullucus tuberosus (Basellaceae). Plant Pathol. 68:576-587.

Franco, E., ed. 1994. Catálogo de Semilla Básica de Papa en el Perú, Proyecto de Apoyo a la Producción de Semilla e Investigación para Mejorar la Productividad de Papa en el Perú. SEINPA, Lima, Perú.

French, E. R., ed. 1972. Prospects for the Potato in the Developing World. Centro Internacional de la Papa, Lima, Peru.

Fribourg, C. E., and de Zoeten, G. A. 1970. Antiserum preparation and partial purification of potato virus A. Phytopathology 60:1415-1421.

Fribourg, C. E., Gibbs, A. J., Adams, I. P., Boonham, N., and Jones, R. A. C. 2019. Biological and molecular properties of wild potato mosaic virus isolates from pepino (Solanum muricatum). Plant Dis. 103: 1746-1756

Fuentes, S., Jones, R. A. C., Matsuoka, H., Ohshima, K., Kreuze, J., and Gibbs, A. J. 2019. Potato virus Y; the Andean connection. Virus Evol. 5:vez037.

Gao, F., Kawakubo, S., Ho, S. Y. and Ohshima, K. The evolutionary history and global spatio-temporal dynamics of potato virus Y. Virus Evol. In press. doi: $10.1093 / \mathrm{ve} / \mathrm{veaa} 056$

German, T. L. 2001. Potato virus A. Pages 676-677 in: Compendium of Potato Diseases, 2nd ed. W. R. Stevenson, R. Loria, G. D. Franc, and D. P. Weingartner, eds. American Phytopathological Society, St. Paul, MN, U.S.A.

Gibbs, A. J., Hajizadeh, M., Ohshima, K., and Jones, R. A. C. 2020. The potyviruses: An evolutionary synthesis is emerging. Viruses 12:132.

Gibbs, A. J., Ohshima, K., Yasaka, R., Mohammadi, M., Gibbs, M. J., and Jones, R. A. C. 2017. The phylogenetics of the global population of potato virus $\mathrm{Y}$ and its necrogenic recombinants. Virus Evolution 3:p.vex002. 
Gibbs, M. J., Armstrong, J. S., and Gibbs, A. J. 2000. Sister-Scanning: A Monte Carlo procedure for assessing signals in recombinant sequences. Bioinformatics 16:573-582.

Glendinning, D. R. 1983. Potato introductions and breeding up to the 20th century. New Phytol. 94:479-505.

Guindon, S., and Gascuel, O. 2003. A simple, fast, and accurate algorithm to estimate large phylogenies by maximum likelihood. Syst. Biol. 52:696-704.

Gutiérrez, P. A., Alzate, J. F., and Montoya, M. M. 2015. Genome sequence of a virus isolate from tamarillo (Solanum betaceum) in Colombia: Evidence for a new potyvirus. Arch. Virol. 160:557-560.

Hajizadeh, M., Gibbs, A. J., Amirnia, F., and Glasa, M. 2019. The global phylogeny of Plum pox virus is emerging. J. Gen. Virol. 100:1457-1468.

Hall, T. A. 1999. BioEdit: A user-friendly biological sequence alignment editor and analysis program for Windows 95/98/NT. Nucleic Acids Symp. Ser. 41:95-98.

Haston, E., Richardson, J. E., Stevens, P. F., Chase, M. W., and Harris, D. J. 2009. The Linear Angiosperm Phylogeny Group (LAPG) III: A linear sequence of the families in APG III. Bot. J. Linn. Soc. 161:128-131.

Hawkes, J. G. 1978. History of the potato. Pages 1-14 in: The Potato Crop. P. M. Harris, ed. Springer Publishers, Dordrecht, The Netherlands.

Hawkes, J. G. 1990. The Potato: Evolution, Biodiversity and Genetic Resources. Belhaven Press, London, U.K.

He, C., Zhang, W., Hu, X., Singh, M., Xiong, X., and Nie, X. 2014. Molecular characterization of a Chinese isolate of potato virus A (PVA) and evidence of a genome recombination event between PVA variants at the $3^{\prime}$-proximal end of the genome. Arch. Virol. 159:2457-2462.

Holmes, E. C., Worobey, M., and Rambaut, A. 1999. Phylogenetic evidence for recombination in dengue virus. Mol. Biol. Evol. 16:405-409.

Howard, H. W., and Fuller, M. 1965. The inheritance of top-necrosis to potato viruses X, A, B and C in Solanum tuberosum. Euphytica 14:189-195.

Hughes, A. L. 2009. Small effective population sizes and rare nonsynonymous variants in potyviruses. Virology 393:127-134.

Insuasti, M. L., Ochoa, J. B., Martin, R. R., Alvarez, R. A., and Quito-Avila, D. F. 2016. First report of potato virus V and Peru tomato mosaic virus on tamarillo (Solanum betaceum) orchards of Ecuador. Plant Dis. 100:868.

Jaramillo, M., Gutiérrez, P. A., Lagos, L. E., Cotes, J. M., and Marín, M. 2011. Detection of a complex of viruses in tamarillo (Solanum betaceum) orchards in the Andean region of Colombia. Trop. Plant Pathol. 36: 150-159.

Jeanmougin, F., Thompson, J. D., Gouy, M., Higgins, D. G., and Gibson, T. J. 1998. Multiple sequence alignment with Clustal X. Trends Biochem. Sci. 23:403-405.

Jones, R. A. C. 1987. Problems associated with potyviruses in potato certification - field inspection and serological testing. EPPO Bull. 17:61-67.

Jones, R. A. C. 1990. Strain group specific and virus specific hypersensitive reactions to infection with potyviruses in potato cultivars. Ann. Appl. Biol. 117:93-105.

Jones, R. A. C. 2014. Virus disease problems facing potato industries worldwide: Viruses found, climate change implications, rationalizing virus strain nomenclature and addressing the Potato virus Y issue. Pages 202-224 in: The Potato: Botany, Production and Uses. R. Navarre and M. J. Pavek, eds. CABI, Wallingford, U.K.

Karasev, A. V., and Gray, S. M. 2013. Continuous and emerging challenges of Potato virus $\mathrm{Y}$ in potato. Annu. Rev. Phytopathol. 51:571-586.

Katoh, K., and Standley, D. M. 2013. MAFFT multiple sequence alignment software version 7: Improvements in performance and usability. Mol. Biol. Evol. 30:772-780.

Kehoe, M. A., and Jones, R. A. C. 2011. A proposal to help resolve the disagreement between naming of potato virus $\mathrm{Y}$ strain groups defined by resistance phenotypes and those defined by sequencing. Arch. Virol. 156: 2273-2278.

Kehoe, M. A., and Jones, R. A. C. 2016. Improving Potato virus Y strain nomenclature: Lessons from comparing isolates obtained over a 73-year period. Plant Pathol. 65:322-333.

Kekarainen, T., Merits, A., Oruetxebarria, I., Rajamäki, M.-L., and Valkonen, J. P. T. 1999. Comparison of the complete sequences of five different isolates of potato virus A (PVA), genus Potyvirus. Arch. Virol. 144:2355-2366

Kreuze, J. F., Souza-Dias, J. A. C., Jeevalatha, A., Figueira, A. R., Valkonen, J. P. T., and Jones, R. A. C. 2020. Viral diseases in potato. Pages 389-430 in: The Potato Crop. H. Campos and O. Ortiz, eds. Springer, Cham, Switzerland.

Lemey, P., Lott, M., Martin, D. P., and Moulton, V. 2009. Identifying recombinants in human and primate immunodeficiency virus sequence alignments using quartet scanning. BMC Bioinf. 10:126.

Loebenstein, G., Berger, P. H., Brunt, A. A., and Lawson, R. H., eds. 2001. Virus and Virus-like diseases of Potatoes and Production of Seed-Potatoes. Kluwer Academic Publishers, Dordrecht, The Netherlands.

MacLachlan, D. S., Larson, R. H., and Walker, J. C. 1954. Potato virus A. Am. Potato J. 31:67-72.
Martin, D. P., Murrell, B., Golden, M., Khoosal, A. and Muhire, B. 2015. RDP4: Detection and analysis of recombination patterns in virus genomes. Virus Evol. 1:vev003.

Martin, D. P., Posada, D., Crandall, K. A., and Williamson, C. 2005. A modified bootscan algorithm for automated identification of recombinant sequences and recombination breakpoints. AIDS Res. Hum. Retroviruses 21:98-102.

Martin, D. P., and Rybicki, E. 2000. RDP: Detection of recombination amongst aligned sequences. Bioinformatics 16:562-563.

Maynard-Smith, J. M. 1992. Analyzing the mosaic structure of genes. J. Mol. Evol. 34:126-129.

McGuire, G., and Wright, F. 2000. TOPAL 2.0: Improved detection of mosaic sequences within multiple alignments. Bioinformatics 16:130-134

Mohammadi, M., Gibbs, A. J., Hosseini, A., and Hosseini, S. 2018. An Iranian genomic sequence of Beet mosaic virus provides insights into diversity and evolution of the world population. Virus Genes 54:272-279.

Mortensen, R. J., Shen, X., Reid, A., and Mulholland, V. 2010. Characterization of viruses infecting potato plants from a single location in Shetland, an isolated Scottish archipelago. J. Phytopathol. 158:633-640.

Mossop, D. W. 1977. Isolation, purification, and properties of tamarillo mosaic virus, a member of the potato virus Y group. N. Z. J. Agric. Res. 20:535-541.

Murphy, P. A., and McKay, R. 1932a. The compound nature of crinkle and its production by means of a mixture of viruses. Sci. Proc. R. Dublin Soc. 5:227-247.

Murphy, P. A., and McKay, R. 1932b. A comparison of some American and European potato viruses. Sci. Proc. R. Dublin Soc. 5:347-358.

Nisbet, C., Monger, W. A., Ross, S., Holmes, R. F., Nova, Y., Thomson, C., Goodfellow, H. A., Lacomme, C., and Jeffries, C. J. 2019. Biological and molecular characterization of Potato yellow blotch virus, a new species of the genus potyvirus. Plant Pathol. 68:251-260.

Nunn, N., and Qian, N. 2010. The Columbian Exchange: A history of disease, food and ideas. J. Econ. Perspect. 24:163-188.

Ondov, B. D., Bergman, N. H., and Phillippy, A. M. 2011. Interactive metagenomic visualization in a web browser. BMC Bioinf. 12:385.

Padidam, M., Sawyer, S., and Fauquet, C. M. 1999. Possible emergence of new geminiviruses by frequent recombination. Virology 265:218-225.

Posada, D., and Crandall, K. A. 2001. Evaluation of methods for detecting recombination from DNA sequences: Computer simulations. Proc. Natl. Acad. Sci. U.S.A. 98:13757-13762.

Prohens, J., and Nuez, F. 2001. The tamarillo (Cyphomandra betacea): A review of a promising small fruit crop. Small Fruits Rev. 1:43-68.

Rajamäki, M., Merits, A., Rabenstein, F., Andrejeva, J., Paulin, L., Kekarainen, T., Kreuze, J. F., Forster, R. L. S., and Valkonen, J. P. T. 1998. Biological, serological, and molecular differences among isolates of potato A potyvirus. Phytopathology 88:311-321.

Rambaut, A., Lam, T. T., Carvalho, L. M., and Pybus, O. G. 2016. Exploring the temporal structure of heterochronous sequences using TempEst. Virus Evol. 2:vew007.

Rutschmann, F. 2006. Molecular dating of phylogenetic trees: A brief review of current methods that estimate divergence times. Diversity and Distributions 12:35-48.

Santillan, F. W., Fribourg, C. E., Adams, I. P., Gibbs, A. J., Boonham, N., Kehoe, M. A., Maina, S., and Jones, R. A. C. 2018. The biology and phylogenetics of Potato virus $\mathrm{S}$ isolates from the Andean region of South America. Plant Dis. 102:869-885.

Seminario-Cunya, J. 2008. Diversidad y Variabilidad de Papa, con Enfasis en el Norte Peruano. Universidad Nacional de Cajamarca, Cajamarca, Peru.

Shimodaira, H., and Hasegawa, M. 1999. Multiple comparisons of log-likelihoods with applications to phylogenetic inference. Mol. Biol. Evol. 16:1114.

Smith, K. M. 1957. A textbook of Plant Virus Diseases, 2nd ed. Churchill Ltd., London, U.K.

Solomon-Blackburn, R. M., and Barker, H. 2001. A review of host major-gene resistance to potato viruses $\mathrm{X}, \mathrm{Y}, \mathrm{A}$ and $\mathrm{V}$ in potato: Genes, genetics and mapped locations. Heredity 86:8-16.

Valkonen, J. P. T. 2007. Viruses: Economical losses and biotechnological potential. Pages 619-641 in: Potato Biology and Biotechnology: Advances and Perspectives. D. Vreugdenhil, ed. Elsevier Science, Amsterdam, The Netherlands.

Valkonen, J. P. T., Puurand, Ü., Slack, S. A., Mäkinen, K., and Saarma, M. 1995. Three strain groups of potato A potyvirus based on hypersensitive responses in potato, serological properties, and coat protein sequences. Plant Dis. 79:748-753.

Waters, M. R. 2019. Late Pleistocene exploration and settlement of the Americas by modern humans. Science 365 :eaat 5447 .

Zadoks, J. C. 2008. The potato murrain on the European continent and the revolutions of 1848. Potato Res. 51:5-45.

Zheng, Y., Gao, S., Padmanabhan, C., Li, R., Galvez, M., Gutierrez, D., Fuentes, S., Ling, H.-S., Kreuze, J., and Fei, Z. 2017. VirusDetect: An automated pipeline for efficient virus discovery using deep sequencing of small RNAs. Virology 500:130-138. 